\title{
A new Gongylidioides Oi, 1960 from Taiwan (Aranei: Linyphiidae)
}

\section{Новый вид рода Gongylidioides Oi, 1960 из Тайваня (Aranei: Linyphiidae)}

\author{
Andrei V. Tanasevitch ${ }^{1}$, Yuri M. Marusilk ${ }^{2,3,4}$ \\ А.В. Танасевич ${ }^{1}$, Ю.М. Марусик ${ }^{2,3,4}$
}

\footnotetext{
${ }^{1}$ A.N. Severtsov Institute of Ecology and Evolution, Russian Academy of Sciences, Russia. E-mail: tanasevitch@gmail.com

${ }^{1}$ Институт проблем экологии и эволюции им. А.Н. Северцова РАН, Ленинский проспект 33, Москва 119071, Россия.

${ }^{2}$ Institute for Biological Problems of the North FEB, Russian Academy of Sciences, Russia. E-mail: yurmar@mail.ru

2 Институт биологических проблем Севера, ДВО РАН, ул. Портовая, 18, 685000 Магадан, Россия.

${ }^{3}$ Department of Zoology \& Entomology, University of the Free State, Bloemfontein 9300, South Africa.

${ }^{4}$ Zoological Museum, Biodiversity Unit, FI-20014 University of Turku, Finland.
}

KEY WORDS: taxonomy, spiders, Erigoninae, Oriental Region, southeastern Asia.

КЛЮЧЕВЫЕ СЛОВА: таксономия, пауки, Erigoninae, Ориентальное царство, юго-восточная Азия.

ABSTRACT. A new species, Gongylidioides protegulus sp.n., is described from Chiayi and Pingtung counties of Taiwan. The new species differs from the known congeners by the structure of the copulatory organs, mainly by the long, thin, looped embolus and conically protruded, membraneous protegulum, as well as by the shape of the epigynal ventral plate.

How to cite this article: Tanasevitch A.V., Marusik Yu.M. 2019. A new Gongylidioides Oi, 1960 from Taiwan (Aranei: Linyphiidae) // Arthropoda Selecta. Vol.28. No.1. P.152-156. doi: 10.15298/arthsel. 28.1.14

РЕЗЮМЕ. Из двух округов Тайваня, Цзяи и Пиндун, описан новый вид Gongylidioides protegulus sp.n. Вид отличается от ближайших представителей рода структурой копулятивных органов, а именно, длинным, тонким, кольцевым эмболюсом, конически вытянутым мембранизированным протегулюм, а также специфической формой вентральной пластинки эпигины.

\section{Introduction}

Currently, the spider genus Gongylidioides Oi, 1960 includes 17 species, distributed in southeastern Palaearctic and in the Oriental Region [World Spider Cata$\log , 2018]$. The genus is relatively well studied due to several publications including a regional revision of Chinese species [Tu, Li, 2006]; a survey of species occurring in Japan [Ono et al., 2009] and some occasional descriptions [Tanasevitch, 2011; Yin et al., 2012]. Two species, G. angustus Tu et Li, 2006 and G. diellipticus Song et Li, 2008, have been described from Taiwan [Tu, Li, 2006; Song, Li, 2008] and since then they have not been found anywhere. While studying material recently collected in southern part of Taiwan, we found a new species of Gongylidioides, a description of which is given below.

\section{Material and methods}

This paper is based on material kept at the Muséum d'histoire naturelle de Genève, Switzerland (MHNG), as well as collected by junior author and Peter Jäger in Taiwan in 2013. Type material is shared between the MHNG; the National Museum of Natural Science, Taichung, Taiwan (NMNS); the Senckenberg Museum, Frankfurt am Main, Germany (SMF); the Zoological Museum of the Moscow State University, Moscow, Russia (ZMMU); and the Zoological Museum of Turku University, Turku, Finland (ZMTU).

Specimens preserved in $70 \%$ ethanol were studied using a stereomicroscope MBS-9. Photographs were taken using different-sized dishes with a paraffin layer on the bottom, using an Canon EOS 7D camera attached to an Olympus SZX16 stereomicroscope and with a SEM JEOL JSM-5200 scanning microscope at the Zoological Museum, University of Turku. Digital images were prepared using the "CombineZP" image stacking software.

The terminology of copulatory organs mainly follows that of Merrett [1963], Hormiga [2000] and Tanasevitch $[1998,2015]$. The chaetotaxy is given in a formula, e.g., 2.2.1.1, which refers to the number of dorsal spines on tibiae I IV. The sequence of leg segment measurements is as follows: femur + patella + tibia + metatarsus + tarsus. All measurements are given in $\mathrm{mm}$. All scale bars in the figures correspond to $0.1 \mathrm{~mm}$, unless indicated otherwise. Figure numbers are given above the scale lines, the corresponding distance below.

The following abbreviations are used in the text in figures: C - convector sensu Tanasevitch [1998] (= lamella sensu Merrett [1963]); D — duct; DAC — distal apophysis of convector sensu Tanasevitch [2015]; DSA — distal suprategular apophysis sensu Hormiga [2000]; E - embolus; $\mathrm{F}$ - fold; Fe - femur; LEC - lateral extension of convec- 

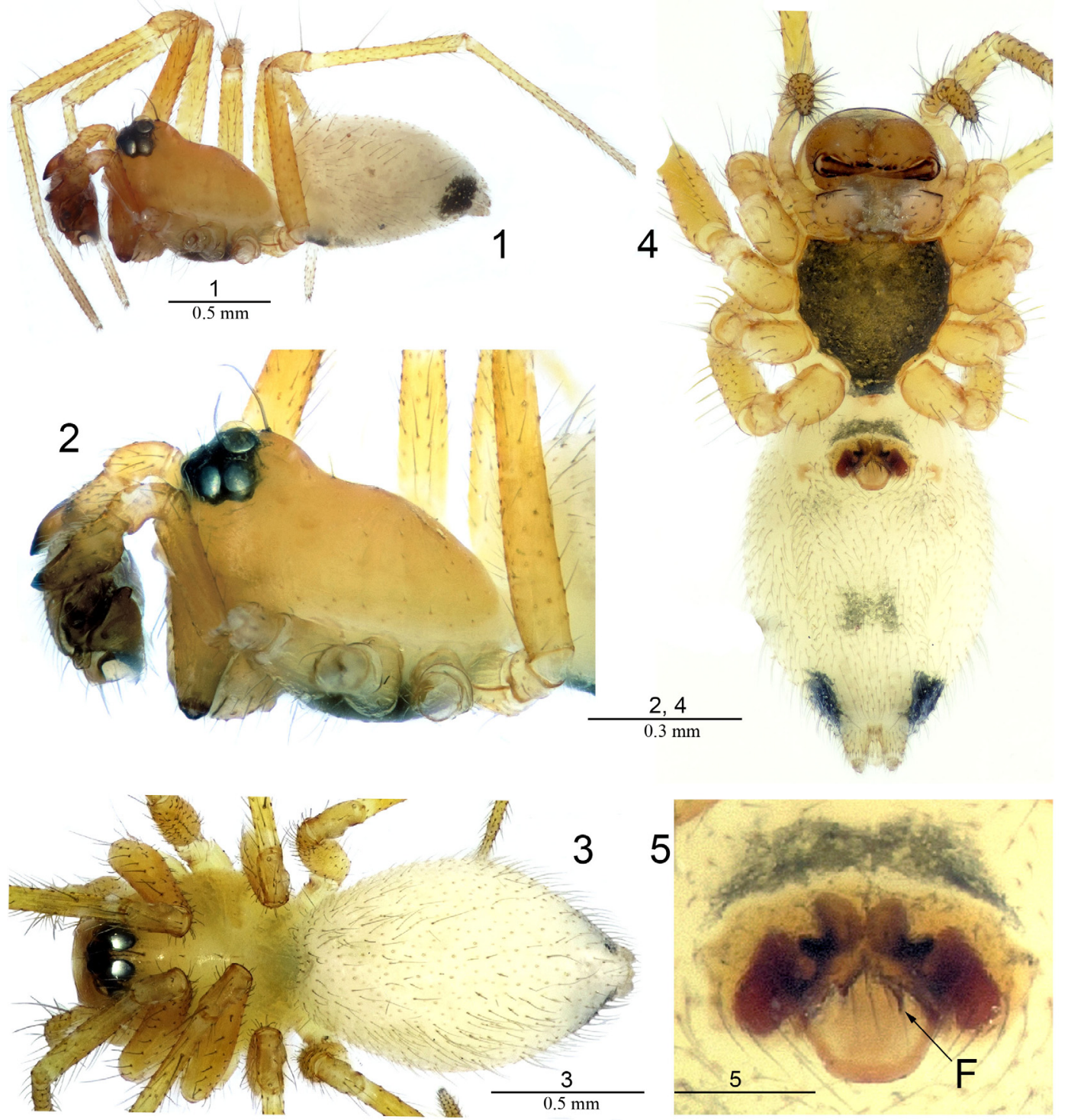

Figs 1-5. Gongylidioides protegulus sp.n., $\sigma^{\top}(1-2)$ and $+(3-5)$ paratypes from Pingtung County). $1-\bigcirc^{\top}$ body, lateral view; $2-\bigcirc^{7}$ prosoma, lateral view; $3-4-$ - body, dorsal and ventral views, respectively; 5 - epigyne, ventral view.

Pис. 1-5. Gongylidioides protegulus sp.n., $\sigma^{7}(1-2)$ и 9 (3-5) паратипы из округа Пиндун. $1-\sigma^{7}$ тело, вид сбоку; $2-\bigcirc^{7}$ просома, вид сбоку; 3-4 - क тело, вид сверху и снизу, соответственно; 5 - эпигина, вид снизу.

tor sensu Tanasevitch [2015]; FD — fertilization duct; MC main body of convector; Pro - protegulum; Re - receptacle; RTA - retrolateral tibial apophysis; T - tegulum; TmI - position of trichobothrium on metatarsus I; VP ventral plate.

\section{Description}

Genus Gongylidioides Oi, 1960

Type species: Gongylidioides cucullatus Oi, 1960, by original designation and monotypy.

\section{Gongylidioides protegulus sp.n.}

Figs 1-17.
HOLOTYPE O $0^{7}$ (MHNG), TAIWAN, Chiayi County, Alishan, Rd. 129, km 15.5, after Tanaïgu, $600 \mathrm{~m}$ a.s.l., dead leaves, 13.IV.2009, leg. S. Vit [TAIW-09/22].

PARATYPES: 1 , collected together with holotype; $10^{7}, 6$ 오 (NMNS), $20^{7} 0^{7}, 7$ 우 (ZMMU), $2 ᄋ^{7} 0^{7}, 4$ 우 (ZMTU), TAIWAN, Pingtung County, Kenting National Park, $21^{\circ} 58^{\prime} \mathrm{N} 120^{\circ} 50^{\prime} \mathrm{E}$, sifting litter, hand picking among grass and stones, 26.VI.2013, leg. Y. Marusik; 3 우 (SMF), Kenting Nature Park, 21 $1^{\circ} 57^{\prime} 25.97 " \mathrm{~N}$ $120^{\circ} 49^{\prime} 13.29$ "E, $200 \mathrm{~m}$ a.s.l., disturbed primary forest, limestones, at day, by hand, 26.VI.2013, leg. P. Jäger.

DIAGNOSIS: Gongylidioides protegulus sp.n. is most similar to G. angustus Tu et $\mathrm{Li}, 2006$, a species also known from Taiwan. The new species can be distinguished by the falcate retrolateral outgrowth of the palpal tibia (almost straight in G. angustus), by the significantly thinner and longer embolus (Figs 6-7, 11 cf. Figs $2(\mathrm{c}-\mathrm{g}$ ) in $\mathrm{Tu} \& \mathrm{Li}$ [2006]), by the shape of the convector (named as lamella 

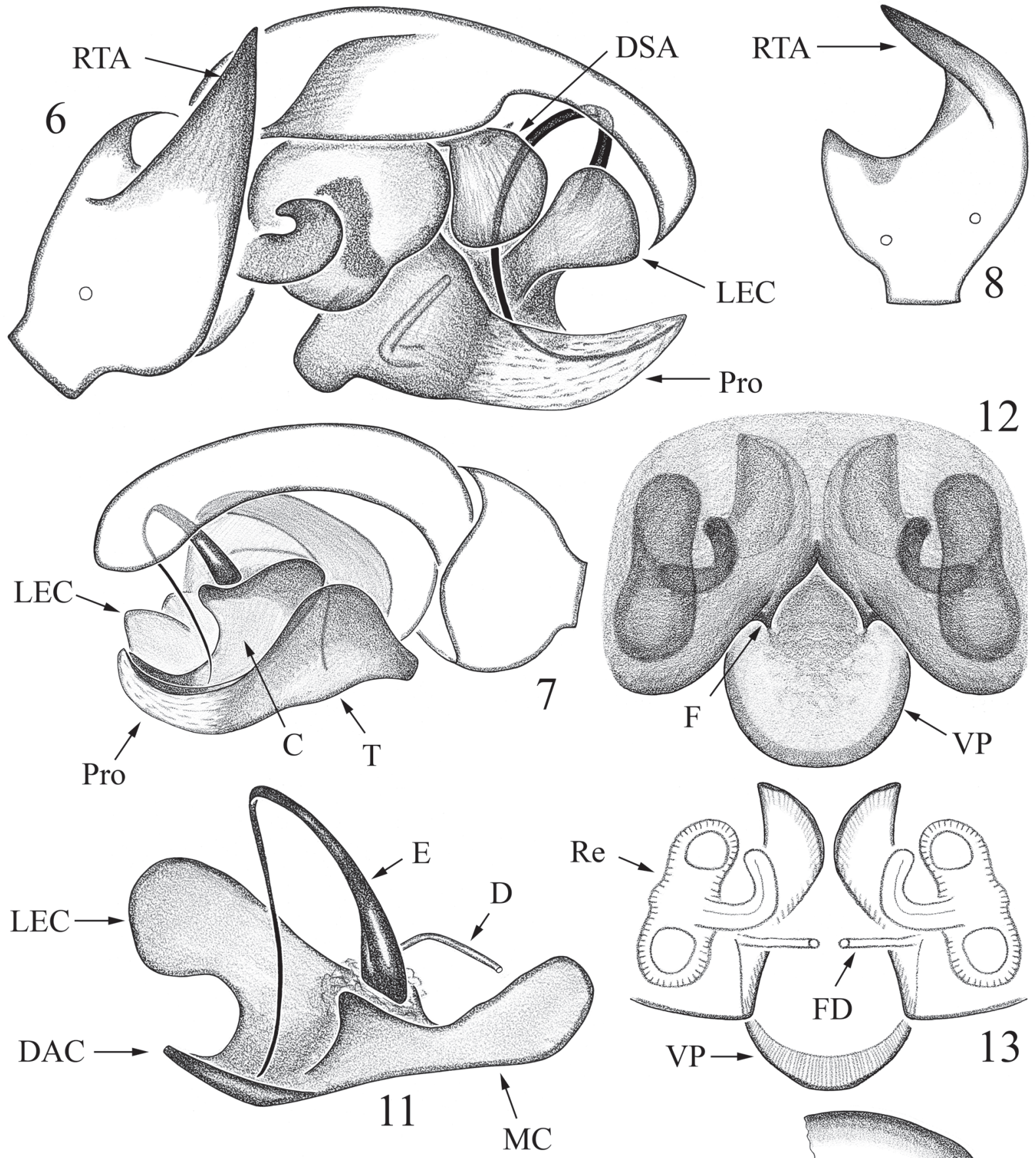

7
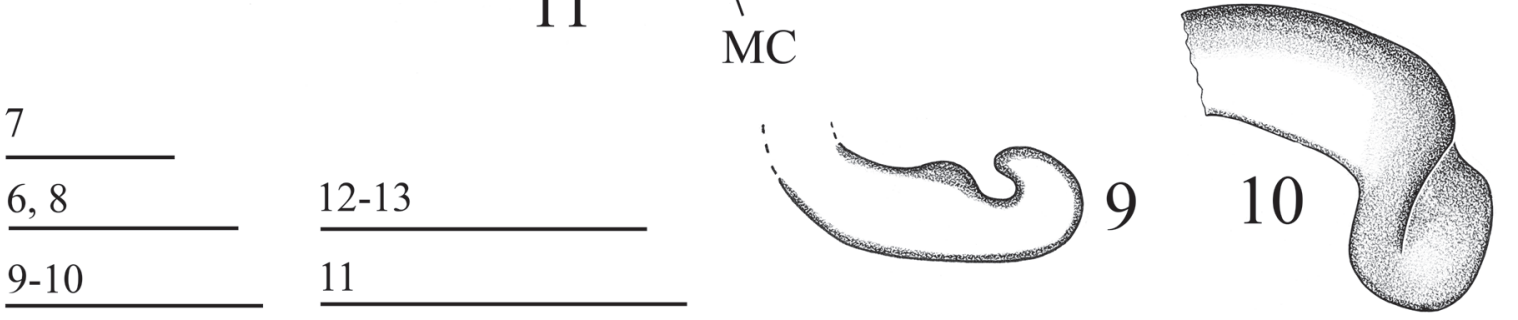

Figs 6-13. Gongylidioides protegulus sp.n., $\mathrm{O}^{7}(6-11)$ and + (12-13) paratypes from Pingtung County. 6-7 — right palp, retrolateral and prolateral views, respectively; 8 - palpal tibia, dorsal view; 9 - paracymbium; 10 - distal suprategular apophysis, lateral view; 11 embolic division; 12 - epigyne, ventral view; 13 - cleared epigyne, dorsal view.

Pис. 6-13. Gongylidioides protegulus sp.n., o (6-11) и + (12-13) паратипы из округа Пиндун. 6-7 - правая пальпа, ретро- и пролатерально, соответственно; 8 - голень пальпы, вид сверху; 9 - парацимбиум; 10 - дистальная супратегулярная апофиза, вид сбоку; 11 - эмболюсный отдел; 12 - эпигина, вид снизу; 13 - просветлённая эпигина, вид сверху. 

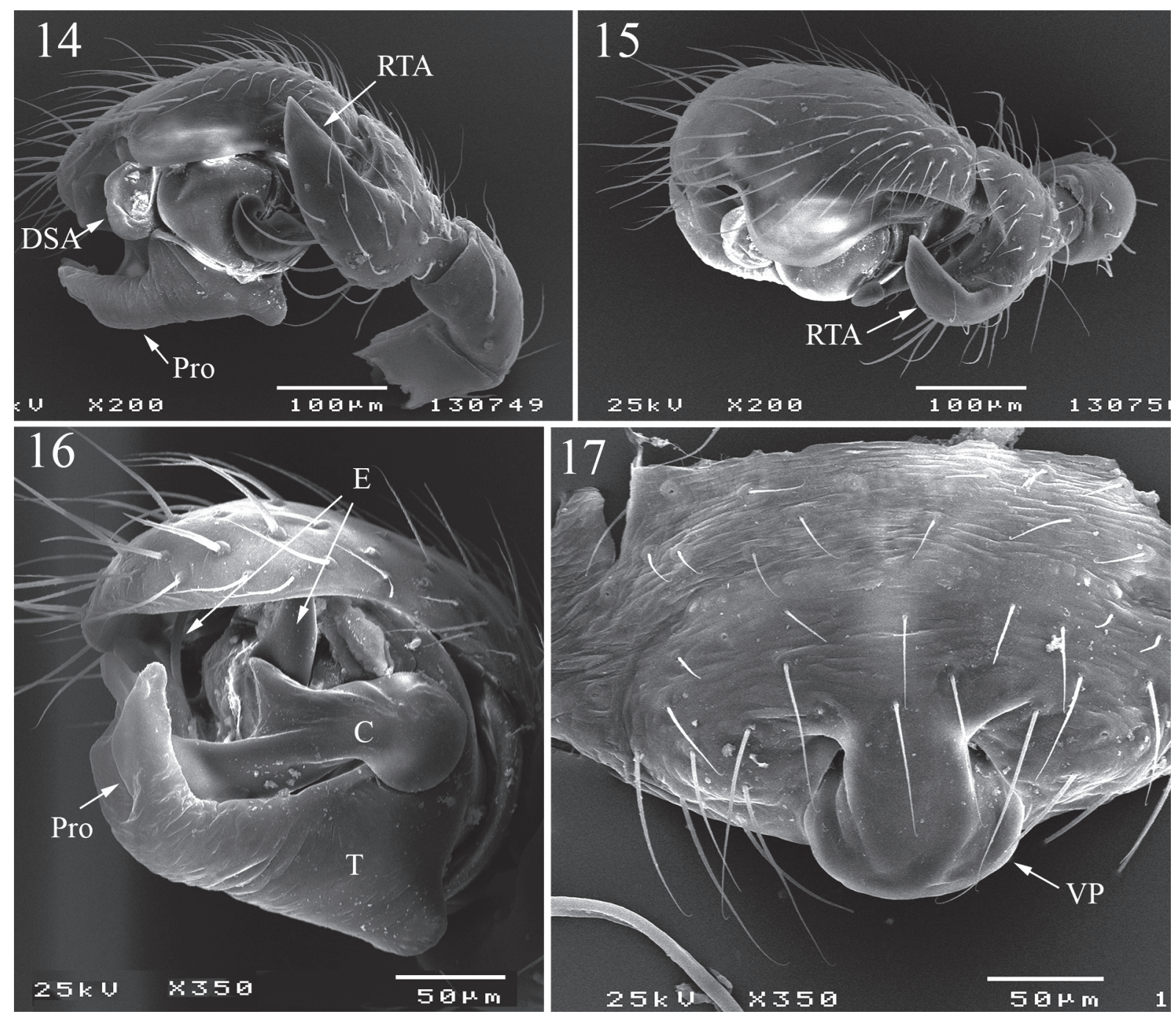

Figs 14-17. Gongylidioides protegulus sp.n., $\sigma^{\top}(14-16)$ and + (17) paratypes from Pingtung County. 14-16 - left palp, retrolateral, dorsal and ventral views, respectively; 17 - epigyne, ventral view.

Рис. 14-17. Gongylidioides protegulus sp.n., ○’ (14-16) и + (17) паратипы из округа Пиндун. 14-16 - левая пальпа, ретролатерально, дорсально и вентрально, соответственно; 17 - эпигина, вид снизу.

characteristica in $\mathrm{Tu} \& \mathrm{Li}$ [2006]), as well as by the conically protruded, almost transparent, membraneous protegulum in male. The females of new species differ by the parallel configuration of the receptacles (diverging in G. angustus), as well as by the presence of two small, pointed folds ( $\mathrm{F}$ in Figs 5,12 ) on the anterior wall of the epigyne, which translucent through the ventral plate. In addition, receptacles are larger than copulatory ducts in G. protegulus sp.n. and smaller in G. angustus.

ETYMOLOGY: The specific name is a noun in apposition, refers to a large and long protegulum.

DESCRIPTION: Male (paratype from Pingtung County). Total length 1.83, habitus as in Fig. 1. Carapace weakly modified: cephalic area slightly elevated, bearing a spine, directed anterodorsally as shown in Fig. 2; 0.80 long, 0.65 wide, yellow to pale brown. Eyes slightly enlarged, lateral eyes equal in size to posterior median, sulci absent. Sternum and labium almost black. Chelicerae 0.28 long. Legs and palps yellow. Leg I 2.91 long $(0.75+0.25+0.75+0.68+$ $0.48)$, IV 2.86 long $(0.75+0.23+0.73+0.70+0.45)$.
Chaetotaxy 2.2.1.1, length of spines about 1.5-2.5 diameters of corresponding segment. TmI 0.65. All metatarsi with a trichobothrium. Palp (Figs 6-11, 14-16): tibia with a large, falcate retrolateral apophysis. Cymbium without posterodorsal process. Paracymbium narrow, L-shaped. Tegulum with a basal, rounded projection, distally with a conically, well-protruded, almost transparent membranous protegulum. Median membrane reduced. Convector massive, its distal apophysis narrow, pointed, lateral extension expanded distally. Radix reduced, embolus long, narrow, making a loop. Abdomen 1.08 long, 0.63 wide, dorsally white, ventrally with two black spots near spinnerets as in Fig. 1.

Female (from Pingtung County). Total length 1.88, habitus as in Figs 3-4. Carapace unmodified, 0.83 long, 0.68 wide, eyes normal. Chelicerae 0.38 long. Leg I 2.81 long $(0.75+0.25+0.73+0.63+0.45)$, IV 2.76 long $(0.78+$ $0.20+0.75+0.63+0.40)$. TmI 0.67. Epigyne $(4-5,12-13$, 17): ventral plate narrowing anteriorly; expanded, rounded and well-protruded distad. Anterior wall with two small, pointed folds ( $\mathrm{F}$ in Figs 5, 12), which translucent through 
the ventral plate. Receptacles bean shaped. Abdomen 1.08 long, 0.75 wide, dorsally white, ventral pattern as in Fig. 4. Prosoma and leg coloration, chaetotaxy, as in male.

DISTRIBUTION: Known only from Chiayi and Pingtung counties in Taiwan.

Acknowledgements. We are most grateful to Peter Schwendinger (MHNG) and Peter Jäger (SMF) for the opportunity to work with the museum collections under their care.

\section{References}

Hormiga G. 2000. Higher level phylogenetics of erigonine spiders (Araneae, Linyphiidae, Erigoninae) // Smithsonian Contributions to Zoology. Vol. 609. P.1-160.

Merrett P. 1963. The palpus of male spiders of the family Linyphiidae // Proceedings of the Zoological Society of London. Vol. 140. P.347-467

Ono H., Matsuda M., Saito H. 2009. Linyphiidae, Pimoidae // Ono H. (ed.). The Spiders of Japan with keys to the families and genera and illustrations of the species. Kanagawa: Tokai University Press. P.253-344.

Song Y.J., Li S.Q. 2008. A taxonomic study of five erigonine spiders (Araneae: Linyphiidae) from China // Arthropoda Selecta. Vol.17. No.1-2. P.87-100.

Tanasevitch A.V. 1998. Gorbothorax n. gen., a new linyphiid spider genus from the Nepal Himalayas (Arachnida, Araneae, Linyphiidae) // Bonner Zoologische Beiträge. Bd.47. P.421-428.

Tanasevitch A.V. 2011. Linyphiid spiders (Araneae, Linyphiidae) from Pakistan and India // Revue suisse de Zoologie. T.118. Fasc.3. P.561-598.

Tanasevitch A.V. 2015. Notes on the spider genus Oedothorax Bertkau, 1883 with description of eleven new species from India (Linyphiidae: Erigoninae) // Revue suisse de Zoologie. T.122. Fasc.2. P.381-398.

Tu L.H., Li S.Q. 2006. A review of Gongylidioides spiders (Araneae: Linyphiidae: Erigoninae) from China // Revue suisse de Zoologie. T.113. Fasc.1. P.51-65.

World Spider Catalog. 2018. World Spider Catalog, version 19.0. Natural History Museum Bern. Online at http://wsc.nmbe.ch (accessed in November, 2018)

Responsible editor K.G. Mikhailov 